\title{
ERROR TERMS FOR STEFFENSEN'S, YOUNG'S, AND CHEBYCHEV'S INEQUALITIES
}

\author{
Peter R. MERCER
}

Abstract. We recast the well-known Steffensen's inequality, and a number of its relations, as an equality involving an error term. The same general idea leads to error terms for Young's and Chebychev's inequalities.

Mathematics subject classification (2000): 26D15.

\section{REFERENCES}

[1] A. Hoorfar And F. QI A new refinement of Young's inequality, Mathematical Inequalities \& Applications, 11 (2008), 689-692.

[2] A. MCD.MerCer An "error term" for the Ky Fan inequality, J. Math. Anal. Appl., 220 (1998), 774 777.

[3] D. S. Mitrinović (in Cooperation with P. M. Vasić), Analytic inequalities, Springer-Verlag, New York-Berlin, 1970.

[4] D. S. Mitrinović, J. E. PeČArić, And A. M. Fink, Classical and new inequalities in analysis, Kluwer Academic Publishers Group, Dordrecht, 1993.

[5] C. Niculescu And L.-E. Persson, Convex functions and their applications, CMS Books in Mathematics, Springer, 2006.

[6] A.M. Ostrows Ki, On an integral inequality, Aequationes Math., 4 (1970), 358-373.

[7] J. PeČArić, I. PERIĆ And H. M. SRIVAstava, A family of the Cauchy type mean-value theorems, J. Math. Anal. Appl., 306 (2005), 730-739. 